\title{
IKAP
}

JKAP (Jurnal Kebijakan dan Administrasi Publik) Vol.21 (1), May 2017, 55-75

ISSN 0852-9213 (Print), ISSN 2477-4693 (Online)

Available Online at https://journal.ugm.ac.id/jkap

\section{Functional Decentralization Construct in Decentralization Policy in Indone- sia (A Study of Irrigation, Education, and Free Trade Sectors)}

\author{
Alma'arif \\ Faculty of Government Management, IPDN \\ almaarhief07@gmail.com \\ Irfan Ridwan Maksum \\ Professor of Public Administration Universitas Indonesia \\ irm60@yahoo.com
}

\begin{abstract}
This research analyze the practice of irrigation, education, and free trade governance linked with functional decentralization concept in Indonesia's decentralization policy frame. This research use constructivist approach and qualitative-descriptive method. Research result find several factors that cause functional decentralization in Indonesia's decentralization policy for irrigation, education, and free trade is not adopted. Political institution is not adopted, independence of the farmers, integration of river and irrigation web, and state constitution, are the factors from irrigation side. Several factors in education are the existence of educational boards, the independence of school, devolution in education governance, and state constitution. For free trade, the institution of Batam governance, members structure in Batam's boards, the uncertainty of BP. Batam in Indonesia's administration structure, and state constitution, which make functional decentralization is not adopted. Generally, state constitution is major factor of functional decentralization is not adopted. The Construction of Decentralization in the Future of Indonesia's Decentralization Policy especially in irrigation, education, and free trade can be done gradually begin from inter-local government cooperation, state-local collaboration in boards until establishing the functional decentralization's organization.
\end{abstract}

Keywords: education, free trade, functional decentralization, irrigation, territorial decentralization 


\section{INTRODUCTION}

Decentralization Policy in Indonesia which has been implementation since the country attained independence is not free of problems. The problems relate to the level of decentralization, division of responsibilities, relations between the central and local governments, social conflicts that have affected local governments, disputes among local governments that are still rife and are attributable to many factors, including the implementation of responsibilities and authority. With respect to the administering free trade for example, Batam authority which was established during President Suharto's era as a free trade zone and was envisioned to rival Singapore as one of the growth points in the national economy (hinterland) and was an outcome of the formation of free trade zones and harbors in Indonesia today. To that end, an evaluation of the policy of Batam free zone can serve as a basis that can inform policies on the implementation of free trade zones and harbors in other regions in Indonesia in future. Batan city administration, which was formed on the basis of Law No. 5/1974, is characterized by a highly centralized regulatory framework. Such a regulatory framework ensured easier control of the city administration by the central government in Jakarta. Besides, Batam authority has an institutional framework that is ambiguous, managed under ambiguous mechanisms as whether it falls under centralized, de-concentrated or central government responsibility that is delegated to the city government authority (Maksum, 2016).

With respect to legal framework that underpins Batam management agency (BPBatam), there is a problem of power and authority between (BP-Batam), the former Batam authority and Batam city administration. Law No. 36 / 2000 as amended by Presidential decision No.44 / 2007 on the rights to manage land that is vested to Batam authority and that conferred on Batam city administration. The law vested land that fell under the control of Batam free trade zone and harbor to Batam management agency. The implication of the change was that BP was the only institution that had authority over the control and management of land. Nonetheless, such a status contravenes Law No. $32 / 2004$ on local governments. The contra- vention lies in the fact that the Law No.36/2000 vests upon Batam city administration far more powers and authority than is allowed under Law No.32/2004 on local governments (Murti, 2014). Consequently, such a legal condition, has created coordination problems both vertically and horizontally (Muzwardi, 2015).

The management of Shenzhen free trade zone in China, which initially borrowed a lesson or two from Batam, was based on legal framework that established Shenzhen FTZ as a stakeholder based special area in the region with its own area of operations through administrative reforms that were implemented in 1998 as part and parcel of the Open door policy (Xu, n.d.) (Tantri, 2013) (Lan, 2010).

Nonetheless, problems of institutional ambiguity in the decentralization policy in Indonesia are not only limited to the management of free trade zones, but are also very evident in irrigation policy. Since attaining independence, irrigation has been a crucially important issue in the establishment of regional autonomy in Indonesia. Maksum quotes Hoessein who notes that irrigation issue lies at the root of the formation of several autonomous regions in Indonesia in accordance with Law No. 22 / 1948 that entailed four details for Province; 3 activity details medebewind for large cities and districts; and 2 detailed activities medebewind for municipalies (Maksum, 2006). However, the root cause of the problem in irrigation arose during reformation era with the implementation of Law No. 22 / 1999, which replaced Law No. 5/1974. Despite the fact that irrigation is based on terrain, Law No. 5 / 1974 vested the authority and power over the management of irrigation to provincial governments, and such a status continues to run smoothly. Nonetheless, things changed dramatically with the implementation of Law No. 22 / 1999 when the authority and power to manage irrigation was devolved to district/city governments. The root cause of the problem that Maksum alludes to relates to the over enthusiasm of regional autonomy and de-concentration that is stipulated in Law No. 22 / 1999 which adopts weak local irrigation institutions as traditional institutions. This is because local irrigation institutions, despite being govern- 
ment institutions, are merely charged with implementing programs and activities, but do not have the authority and power to make and issue policies. Besides, local governments were thrown into confusion by the decision which was issued by the constitutional court of republic of Indonesia. The Constitutional court issued a decision No. 85/PUU-XI/2013, which in effect restored the authority to manage and administer irrigation to the provincial level in accordance with Law No. $11 / 1974$ on irrigation that was in turn amended by Law No. 7 / 2004 on water resources. To that end, local governments were in confusion due to the fact that while decentralization and democracy opened way for decentralization of many affairs and responsibilities from the central government to local governments, the constitutional court restored centralized management of irrigation resources at the province level. Confusion became evident in the case of Bandar Lampung city irrigation management that was based on Law No. 7 / 2004, which was line with the decentralization spirit, but was in fact in contravention of Law No. 11/ 1974 as mandated by the constitution court decision on the management of irrigation, which henceforth restored the authority to the provincial government (Hamidah, 2015). The above problems in irrigation are attributable to the fact that the management of irrigation continues to be based on territorial (area) approach, rather than the function of water in line with the flow of the river. To overcome the above problems, regulation and management or irrigation should be under a stakeholder special institution or agency at the province level, and not administered at the city / district level (Kuks, 2002).

Nonetheless, problems that have come in the wake of decentralization are not limited to irrigation and free trade issues but are also evident in the regulatory framework on education provision. The regulation of education policy is based on the devolution of authority to manage, administer and funding from the central government to local governments. Consequently, a problem that has emerged is the inability of local governments to implement the decentralization of education due to the lack of capacity to do so. This is moreover, not to mention major changes that have affected schools, central government and local governments, and society in general (Pasandaran, 2004). In any case, inability of city/district governments to live to their political commitments with regards to the allocation of at least 20 percent of annual regional government expenditure on education every year is as a result of the limited local government revenue capacity (Kuswandi, 2011).

To that end, the existence of problems in the free trade zone, irrigation administration, and education delivery, highlight the fact that decentralization policy in Indonesia has some shortcomings. The constitution stipulates on territorial decentralization without regulating functional decentralization. This is problematic as decentralization is not only limited to territorial or administrative region, but also functions that are conducted within the decentralized region (Hung, 2009). Functional decentralization is the devolution of authority to regulate and administer certain functions that are delimited by the type of function. Functional decentralization can also be defined as the relinquishing of power /authority to regulate and administer certain or some interests (Hoessein, 1993). The Anglo Saxon dictionary defines functional decentralization as a special purpose authorities which is elucidated by Humes (Humes, 1959) as The Specialpurpose authority is distinguished from the special purpose de-concentrated agencies of the central government bureaucratic hierarchy by the fact that it is outside this administrative hierarchy and has a representative governing organ, whose members may be selected in one or more following ways.

The above type of decentralization demands that certain interests are administered by certain groups. Nonetheless, concurrent implementation of territorial and functional decentralization is possible in any country. Functional decentralization is not possible without regional or territorial decentralization, as the former creates a special administrative system that is autonomous at the local level while the latter an autonomous local government (Maksum, 2007).

In fact, functional decentralization policy is not an entirely new concept in the realm of public management in Indonesia. The Dutch East Indian Company regime es- 
tablished waterschappen agency in Indonesia, a measure that was regulated and incorporated into the Dutch Indian Company at the time. The body presaged the formation of Dharma Tirta in Central Java (Maksum, 2006). The existence of the agency was ensured by incorporating it into the Indonesian constitution after the country attained its Independence. Nonetheless, regulation of such institutions as Tirta Dharma from being initiators of policies to implementers by the government is liable to create policy related problems if the role they play transcends nature and functions for which they were established in the first place as enjoined in the decentralization process. To that end, based on a snapshot of the problems that have characterized decentralization policy a conclusion can be drawn that the policy as has been implemented in Indonesia that have been described as lame due to the fact that it has not been effected in the realm of functions. The shortcoming is evident in problems that have arose in the conduct and administration of various affairs or responsibilities which require the use of functional decentralization instruments. Problems in the management of irrigation, free trade zone, and education administration that have been described above will never be resolved as long as management is still limited to regional decentralization. The above conclusion is the overarching motivation of this paper that has the objective of developing a functional decentralization construct in Indonesia.

This study is the first policy research on decentralization policy in Indonesia. Based on the background and title, this study focuses on developing a construct for functional decentralization in Indonesia. Moreover, in light of the background, the research problem for this research problems for this study are formulated into the following research questions 1) why has the decentralization of irrigation, free trade zone, and education sector have not adopted functional decentralization in Indonesia? 2) What should be the construct of decentralization management in irrigation, free trade zone, and education sector administration in Indonesia in future?

\section{RESEARCH METHODS}

To tackle the high complexity of existing perspectives and understanding of the meaning of functional decentralization in areas of irrigation, free trade, and education, this research uses a constructivism approach. The approach facilitates a more comprehensive and extensive search for meaning than would be possible if categorization were used. To that end, the object of this research is the decentralization system in Indonesia, with (BP Batam), Batam city government, Ministry of education and culture, being the locus of the research. Meanwhile, units of analysis for this research included the education office, South Jakarta, State High school 28, South Jakarta, Ciliwung-Cisadane agency (BBWS Cilicis), Ministry of public works and People's housing, local government agency for Ciliwun River basin management (BP DAS Ciliwung) and Directorate General for regional autonomy (Ditjen Otda), Directorate General for regional administration, Directorate General for regional development administration (Ditjen Bina Bangda) Ministry of internal affairs .

In order to use a constructivism approach to analyze functional decentralization, which one of the important components of this research, the research uses analytical framework that is based on level. The level of analysis is used in social sciences to identify and determine differences in scale, location, and size of the object that is the focus of the research. Bocong Li cites Enderle who contends that micro as individuals, meso as organizations, and macro as institutions ( $\mathrm{Li}, 2012)$. In light of that, this research used a micro level analysis of education, irrigation, and trade, while at the meso level, the research compared management practices in education, irrigation, and trade in Indonesia with other countries that have adopted functional decentralization in the three areas. Macro level analysis, tackles government policy on education, irrigation and trade and how the bearing thereof on existing theory.

\section{RESULTS AND DISCUSSION}

Factors that influence the prevent the
adoption functional decentralization in
the Decentralization policy in Indonesia in 


\section{Irrigation, education and free trade sec- tors}

a. Irrigation administration

Decentralization of irrigation administration in Indonesia is underpinned by the need for ensure local government accountability. If irrigation is located in a city/district administration, it becomes the responsibility of the respective city and district administration. Meanwhile, irrigation services that runs across city/district administrations, becomes the responsibility of the provincial government. Based on research findings, several factors were identified as responsible for the absence of functional decentralization in the conduct of tertiary secondary even primary irrigation services. The factors are presented and discussed in the following section.

\section{Non accommodation of political institu- tions}

Ministerial regulation PUPR No. 17 / 2015 on the irrigation commission. The functions and responsibilities of the irrigation commission are stipulated in article 3 to 14 , by dividing irrigation commission in accordance with the area of irrigation. Thus, there is an inter province irrigation commission, provincial irrigation commission, and city/district irrigation commission. Thus, if irrigation administration is juxtaposed with the location of farmers' groups and irrigation networks, it is evident that the management of irrigation is still based on area or region. It has been noted in an earlier section that authority to manage irrigation is vested with city/district governments, while river basins run across several city/ district administrations, managing conflicts between farmers and local governments across city/district administration unavoidable. On the other hand, the legal framework on irrigation commission does not give the irrigation commission the authority to resolve any potential conflicts that may arise. In the event of conflicts, the government establishes a forum that is known as coordination team for river basin water resources management ().

Meanwhile, Minister of public works regulation No. 4 / 2008 on guidelines for
TKPSDA stipulates mechanisms for the formation of area based forums right from the city/district government to those that link provinces. In general, the forums which are established on the basis of decisions that are issued by local government heads and the Minister, are charged with providing coordination services. Meanwhile, regulation of membership of forums becomes the responsibility of parties that are relevant and responsible for irrigation and river basin management. The representative institution, which today continues to serve as the forum that brings various relevant stakeholders, merely serves coordinating and communication roles hence does not have the authority to make policy decisions on irrigation issues. Nonetheless, in the new regulation, the irrigation commission is charged with the task of providing assistance to local government heads (in accordance with the administration level of the commission) in formulating activity plans, recommendations, and inputs in relevant policies. To that end, the representative body can be regarded as an agency that is formed by and accountable to, the local government head, besides, a political institution can be regarded as representative is it owes its existence to the public who conferred upon them the authority to represent and ventilate their aspirations. Such representation occurs if a large section of the public is involved in conferring the authority. This is contrary to conditions on the ground as an official in the Ministry of public works and people's housing acknowledged. An expert in the Ministry of public works and people's housing acknowledged that the number of members of farmers' groups on forums that are charged with tertiary irrigation management does not go beyond 30 persons. The existence of farmers' groups instills and cultivates confidence, trust and ability among farmers to work together to achieve certain objectives, which would not be possible if they were working individually. To that end, farmers' groups are credited for creating mutual trust (Sidik, 2015) as cited from Putnam in what he refers to as social capital. 
Today, farmers /farmers' groups, which are involved in primary and secondary irrigation management are volunteering their services to help local governments. If authority that is vested in farmers' groups which are involved in tertiary irrigation management is elevated at least to secondary irrigation management level, will increase the likelihood of forming a representative institution. This is attributable to the fact that the number of farmers is ever rising. However, based on observations that were made by a certain expert... "If the authority on managing secondary irrigation is increased, difficulties farmers will face will increase as well. The problem lies in the fact that secondary irrigation by its nature is very technical and is capital intensive, both of which capabilities farmers are very wanting". Moreover, according to BBWS Cilicis sources, farmers cannot finance the technical construction of irrigation channels simply because the amount they collect from subscriptions for using irrigation water is not enough to pay for the cost of developing irrigation channels.

\section{Farmers' Independence}

P3A executes management of tertiary irrigation by forming an organization, which consists of members and administrators. The Ministry of Internal affairs regulation No. 50 / 2001 does not contain detailed provisions on the structure that P3A management should take, but states its appointment must be determined by a members' meeting. If the general structure that organizations can serve as an example, management of the organization comprises a head, a deputy head, secretary, and treasurer, all of whom are elected by P3A members in a meeting. Nonetheless, the structure of tertiary irrigation administration is somewhat different from the general form. This is based on information the researcher obtained from an interview with BBWS Cilicis officials who noted that while the structure of the organization consists of management and members, a new structure in addition has a water master. The following excerpt of the interview elucidates the complete story:
"...The local government is charged with regulating water in the context of opening and closing the water gates, a task that rests with the water master (mantra) who acts in consultation with farmers...P3A or GP3A selects individuals who are charged with regulating water, while the water master, who is an employee of the office of agriculture is charged with training farmers on water usage as well as serving as facilitator/serves as coordinator or linkage between P3A and GP3A on one hand and the office of agriculture on the other. The water master is a resident of the village, but is a representative of the office of agriculture who does not earn a salary for his duties."

The excerpt of the interview above gives one the picture that in addition to managers /administrators who are elected by members, farmers groups also have representatives of city/district governments who are charged with the task of providing training on water usage to farmers as well as serve as a communication bridge between farmers and the city/ district agriculture office. Besides, there is also a BBWS Cilicis irrigation work unit that is responsible for regulating and controlling water usage through water gates. The excerpt of the interview with farmers is presented below:

\section{"...if there are direct complaints from farmers about the amount of water that their farms receive, there are water gates control personnel to tackle that problem. Thus, usually farmers convey such complaints directly to water gate control personnel."}

However, on closer observation, it is evident that the form of coordination and relations between P3A and other organizations in regulating and controlling irrigation in agriculture reveals some obstacles that may hamper the performance of P3A. The relations between $\mathrm{P} 3 \mathrm{~A}$ and the water master, P3A and agricultural extension service personnel for irrigation, $\mathrm{P} 3 \mathrm{~A}$ and city/district public works office and P3A and city/district agricultural office. The heavy dependency of P3A on other organ- 
izations has the potential to become a source of bribery. In a research on irrigation dynamics, Maksum discovered that subscriptions for tertiary irrigation water has spawned rent seeking activity among the bureaucracy (Maksum, 2006). In some Dharma Tirta locations where mobilizing irrigation water subscription has proved difficult to realize, access to water has become a matter of "who needs irrigation water is the one who must pay those who have control over the water". Ballesteros corroborates the above situation by the existence of a relationship between functional decentralization and transparency in public service delivery. The higher the degree of functional decentralization, the higher the level of transparency in the delivery of public services (CuadradoBallesteros, 2014)(Cuadrado-Ballesteros, García-Sánchez, Prado-Lorenzo, \& García -Sanchez, 2016).

Subscriptions from P3A members is only one of the sources of P3A income that is recognized by the government. Funds from P3A, GP3A, and IP3A sources as regulated in Ministry of home affairs regulation No.50 / 2001 can be obtained or sourced from (1) subscriptions irrigation management; (2) Non-binding contributions or assistance; (3) other legal economic activities; (4) assistance from the central and local government; and (5) Assistance from foreign foundations/ institutions. The structure of financing P3A through member subscriptions is based on the waterschappen pattern in the Netherland which according to Kuks' elucidation (Kuks, 2002) notes:

"...water boards in other hand, cannot rely on such subsidies, and have to fully recover the costs of their activities by their own taxation. Water boards have a democratic structure, based on a profit-paymentparticipation principle (those having an interest in water management may participate and have to pay for water service in proportion to their interest."

Besides, specifically with respect to irrigation and water, the local government faces the difficulty of making a decision that affects many stakeholders with varied interests. In a detailed account, Sellin (Selin, 2011) asserts that:

"In the specific case of water, questions about responsiveness and intergovernmental coordination are critical as water governance becomes increasingly localized. Communities throughout the nation are facing serious and escalating challenges in securing an adequate water supply and protecting the quality of their drinking water. Local governments will face difficult decisions as they attempt to balance competing demands from different user groups and manage the externalities from their policy choices."

\section{River and irrigation network integra- tion}

The river Ciliwung Cisadane (Cilicis) catchment area that covers three 3 provinces and 10 city/districts makes the issue river management the responsibility of the central government. Meanwhile, with regards to irrigation management, water dams that are located in the upstream section of the rivers and primary and secondary irrigation are to a certain extent the responsibility of the central government. Meanwhile, secondary and tertiary irrigation of certain areal sizes, constitute the responsibility of the provincial, and city/ district governments. This was acknowledged by the expert who was one of the concepts of the Law of local governments who noted that regulatory framework irrigation and river is starkly different. More precisely, he emphasized that

\footnotetext{
"Almost all irrigation networks rarely run from one regional autonomy government to another. Even where that is the case, there is clear demarcation and division in the irrigation system for the two contiguous local governments. That explains why distribution of irrigation system cannot run from one regional autonomy government to another. In fact irrigation area constitutes farm land. Thus, irrigation water comes from water dam rather than from the river, even in areas that are located upstream. Meanwhile, management of a river basin is based on accountability."
}

If irrigation management of river basin was considered from the vantage point of special area, an irrigation system that 
crosses city/districts and provinces should be designated special region. This is very much in line with the argument which an expert who was one of the key informants in this study made to the effect that:

\section{“...Ciliwung-Cisadane irrigation} area can be designated a special region, in not, disasters such as the flash floods that emanated from the leakage of water from Gintung in Banten are unavoidable in the future. This is because it the central government that has the authority but does not control and regulate development in surrounding areas such as was the case in Situ Gintung. Consequently, the local government issued building permits that led to the improper development of the surrounding areas that eventually precipitated the disaster. Once the disaster occurred, no party was ready to assume responsibility."

On the contrary, another informant who is an official in the Ministry of Internal affairs had views that were in contrast to those of the above informant. He implicitly noted that:

“...actually designating a special region is regulated in articles 360 and 361, Law No. 23 / 2014 on local governments. The articles stipulate special zones or areas as defined by two articles in the law. "

In relation to the above statement which the informant from the Ministry of Internal affairs made, it appears that an irrigation area does not meet the requirements that are stipulated in Law No.23/2014 on local governments. Besides, the informant from the Ministry of Internal affairs made additional remarks to the effect that:

"The authority to manage irrigation was exhaustively divided among the central government, provincial, city/ district governments. Yes. Irrigation that occurs in more than one province, falls under the management of the central government, while that between city/district administrations, becomes the responsibility of the province, and irrigation that occurs within one city/ district administration falls under the management of the city/district administration. To that end, the division of authority to management irrigation is very clear, as is stated in the attachment to the law.

...to make things clearer, there is a mechanism that foster cooperation across local governments as well as on issues that relate to formulating government regulations on local government authority within the ambit of a special region or zone. "

Based on the excerpt of the interview above, the inference that can be drawn is that officials in the Ministry of Internal affairs espouse the view that managing irrigation issues can be done through the mechanism of local government cooperation. Moreover, the excerpt of the interview does not indicate that the government, as represented by views of the Ministry of internal affairs, vested more power and authority (empowered) local governments to effectively manage special regions or areas without empowering the local government population.

Besides, based on the acknowledgement of officials from the Ministry of Internal affairs and Ministry of public works and people's housing, cooperation among local governments and sharing of authority and power on the basis of the principle of accountability is only ideal if the irrigation administration is in line with river basin. To that an understanding of the authority and power vested in the local government autonomy is essential for developing functional decentralization in Indonesia that is not based on clear concepts and does not take into account constraints of local governments in managing certain issues and affairs cross local government jurisdiction. Humes (Humes, 1959) acknowledges that the concept of a special district that was developed and adopted in United States of America was motivated by limitations that autonomous regions faced in executing their functions.

b. Education administration

An important pillar in promoting quality education in local governments is not only the responsibility of the central government and local governments, but also 
that of the populace. . Decentralization of education provision offers local governments and schools the opportunity to make the best decisions with respect to the conduct of education in accordance with the potential of the area and stakeholders. Some of the factors that are responsible for the non-incorporation of functional decentralization in education delivery in Indonesia, are presented in the following section.

\section{Existence of the Education council}

The function of the education council is to foster improvement in the quality of education delivery by providing inputs, direction and manpower support, infrastructure and facilities, and supervision of the conduct of education, at the national, provincial, and city /district levels. In addition, the above activities and responsibilities of the education council are complemented by the tasks of collecting, analyzing, and giving recommendations to the Minister, governors, district heads, and mayors, in response to public complaints, advice, and aspirations that relate to education delivery.

According to government regulation No. 17 / 2010, the authority to establish the education council is vested in the head of the local government and the Minister of education. Meanwhile, membership of the council comprises 1) education experts; 2) practitioners of education; 3) businessmen; 4) professional organizations; 5) Religion or socio-culture based specialist education; 6) international education; 7) local competitiveness based education; and 8) social organizations. It is evident that the structure of membership of the council of education consists of representatives that are drawn from a cross section of interests.

In practice, however, the education council does not play as important a role as envisaged. This is an acknowledgement that was made by one of the key informants for this study, who is an official in the center for strategic policy in the Ministry of Education and culture. The excerpt of the interview is presented in the following section: "...the education council is not specifically oriented toward one school, but is based on territory such as the national education council, provincial education council, and city/district education council, making it less effective. I know that because during my tenure as the secretary, it was me who was responsible for selecting membership. This was because at the time, the legal framework was not supported by a decision statement from the minister. None of the education councils at the city/ district level, based on knowledge, has been able to function effectively. Nonetheless, as regards the existence of school committees, they are running smoothly.

...the minister has not yet decided on the formation of a national education council. Consequently, provincial, city/district governments also show reluctance to establish education councils in their respective jurisdictions."

Based on the excerpt of the interview above, regulation and administration of the education council is still territorially based. Such a situation is confirmed by the fact that the establishment of the education council at the local government and national level must be based on decision statement issued by the local government head and Minister of education, respectively. Thus, the head of the city/district government, provincial government, Minister of education and culture, is responsible for establishing education councils at the city/district, province, and national level, respectively. Meanwhile, at the level of an education institution such as a school, the education council takes the form of a school committee.

\section{Independence of schools}

In practice, the role that the school committee plays today is somewhat different from the role previous school committee played. This was revealed in an excerpt of an interview with officials in one of the most renowned schools in South Jakarta, who noted that:

"...The school committee in the past used to assist in mobilizing funding (to support school activities) but school 
committees today are not allowed to do so. Previously, the term used for mobilizing funding was support from society. Currently, funding for schools comes from school operations fund (BOS) from the central government and school operational support from the provincial government (BOP). Thus, parents mobilizing funding from society is prohibited. The implication is that the school committee is today limited to observing and monitoring the conduct of the learning process in schools. Previously, the school committee could provide advice and aspirations toward the policies schools made. It is an activity that is no longer possible because the committee is no longer a source of funding for school activities."

It is thus apparent from the excerpt of the interview above that the school committee today is essentially functionless. Having no role to play in mobilizing funding, coupled with the dominance of government funding for school activities, the school committee has been relegated on the sidelines of school activities. Education expenditure which is based on earmarks or levels has made the school committee and the school unable to undertake any activity that does not fall into the approved school budget. The above condition has put the school at a crossroad between accommodating interests of pupils and students and needs of the school that are funded through expenditure ceiling levels. Most of the budgeting that is contained in a given budgeting ceiling (maximum level), by and large covers academic activities, while nonacademic activities most of which cannot be gauged in line with the needs of the school and tend to differ from one school to the other are financed through general funding. The above situation is compounded by the condition and responsibility of the central government to ensure the successful implementation of the 9- year universal free education. An official who was one of the key informants in the South Jakarta education office had the following to say about the state of school committee and school funding sources:

$$
\text { “...today parents are not al- }
$$

lowed to make any contribution to the school, because the DKI Jakarta government meets all the funding requirements for the school. Thus, the only role the parent plays is to take their children to school. Moreover, the policy is also supported by the central government which allocates 20 percent of the annual budget to education."

Based on the excerpt of the interview above, one of the major weaknesses in the devolution of education provision to local government is the uniformity of programs in schools that have different needs. The implication of that can be the deterioration in the performance of schools and constraints in making use of the education funding allocated due to the fact that not all school needs are accommodated in the budget allocations.

\section{Devolution in the Education manage- ment}

Despite the fact that the government has implemented the use of cluster system in school management at local government level, there are still many areas where education management continues to follow the designated area or zone system. As an example, DKI Jakarta province which an autonomous region, uses a zone or region based model by eliminating the status of high competitive edge which has been associated and attached to some schools. This transpired in an interview which the author of the study conducted with teachers in one of the schools in Jakarta. The excerpt of the interview was as follows:

"...currently there are no longer schools that are categorized as favorite or considered to have a competitive edge over others. That means that all schools have the same status. Nonetheless, there is little doubt in the people's mind they know which schools are considered favorite and those that do not have such a label".

"...Currently, local governments have implemented the quota system in enrolling new students. Many students whose parents reside outside Jakarta, from city outskirts such as Depok and Tangerang. The composition of stu- 
dents is $5 \%$ on the basis of academic performance, $55 \%$ local residents (Mampang, Pancoran, Pasar Minggu, Jagakarsa sub districts), 5\% outside DKI Jakarta, and 35\% general (from within DKI Jakarta)".

In relation to the zone or area based policy above, DKI Jakarta government implemented a new policy in 2016 through decision statement of the head of education office, DKI Jakarta province No.184 / 2016 concerning the designation of school zones within the framework of implementing the new policy on enrolling new students for the 2016/2017 academic year. The new policy is different from the previous one in that $45 \%$ of new students are local and $15 \%$ are students who are not residents of DKI Jakarta. Meanwhile, according to officials in the Ministry of education and culture, the cluster system tantamount to condoning discrimination against students to enroll in good schools. Another perspective on the issue of cluster system in the management of education came to light in an interview with officials in the education office in one of the district governments in South Sulawesi. The excerpt of the interview went as follows:

"The master cluster system as an interesting point in attracting new students as well as an opportunity to increase the amount of funds obtained within the framework of school operations fund (BOS) in the following year, is based on the assumption that the larger the number of students that are enrolled in the school the larger the amount of funds in the form of school operations funds a school will receive. The fund is used in financing school operations. The fund proves helpful in financing the addition of new classes, where there is shortage, making it extremely important for the school."

It is thus apparent that using the cluster model in the management of schools will widen disparity in both quality and physical facilities. On one hand, schools that are cluster I have many students and good facilities, while on the other hand, schools in clusters III-IV do not have enough stu- dents, which by extension means that they have poor physical facilities. An official in the Ministry of Education and Culture confirmed the likelihood of the problem. It is because of the need to avert the problem that led the Ministry of Education and Culture to develop and implement 2013 curriculum which is tailored toward fostering and encouraging quality assurance in every school. In addition, the official reiterated that:

"The emphasis of the Ministry of education is on quality insurance. The starting point of it all is quality control. Since Mr. Muhammad Nuh became the Minister of Education, and introduced 2013 curriculum (K-13) as the starting point of an education regime that puts quality insurance at the front and center of education delivery. Facilities follow school quality assurance. This means that quality assurance is the benchmark that every school is required to achieve in order to guarantee quality education, which influences the facilities the school gets. The K-13 uses a competence standard and standard contents, which every school graduate is required to complete and fulfill. Such standards have implications for the quality of teachers and facilities that schools are expected to have in place. The implementation of $\mathrm{K}-13$ is gradual and phased starting with schools whose students have attained national minimum standard of 6.35. In addition, schools that quality for adopting $K-13$ curriculum must meet another requirement, which is that $70 \%$ of the teachers must be certified."

Based on the excerpt of the interview above, it becomes evident that the Ministry of education and culture implemented $\mathrm{K}-13$ in a phased and gradual way in order to narrow the gap in school quality, which has emerged in the aftermath of the implementation of the decentralization of education to local governments.

\section{c. Free trade administration}

The authority vested in BP. Batam to conduct many functions in its jurisdiction bred new problems when Batam city administration was formed under Law No. 
53 / 1999. Based on our observations, factors that are responsible for the nonadoption of functional decentralization in the realm of free trade administration include the following:

\section{Batam government institutional frame- work}

The democracy and regional autonomy spirit that are based on Laws the central government and local governments is juxtaposed with laws on free trade and free harbors/ports. Batam city government, as an autonomous region, has been directly impacted by the status of BP. Batam which is tasked with conducting many functions (multipurpose). Such impact has been manifested in the inability of the city administration to conduct its functions in accordance with its status as a decentralized administration. BP.Batam practically conducts all functions that are the jurisdiction of Batam city administration. Batam administration city deputy, confirmed such fears in an interview, the excerpt of which is reproduced below:

"...we are unable to move swiftly in delivering public services simply because the function of Batam city government is essentially limited to issuing citizenship identity cards and family cards. This is a direct consequence of the fact that all the functions that would have been under the ambit of Batam city administration are today under the control and direction of BP. Batam. I have one good example. A few days Batam city administration brought to support construction activities in the city but as I speak today which is eight days since the cargo reached the docks, it still has been cleared by BP. Batam authority. .

...son, just imagine as a consequence of the fact that most of the functions that are usually under the aegis of regional autonomy governments are today vested in BP. Batam authority, revenues that Batam city administration from BP. Batam is a mere IDR 800 Billion and IDR 600 Billion from selling land. As regards selling land, even the head of the hamlet is able to do that. What that means is that the organization that we consider as 'our big brother' has yet to manage the authority that vested in it effectively."
On the contrary, an informant from BP. Batam clarified that the existence of BP. Batam and Batam city government will help in accelerating development and service delivery in Batam city. Specifically, excerpt of BP. Batam are reproduced below:

"...see it this way, in the past in accordance with the mandate that is enshrined in Law of local governments, it calls for issuing of a government regulation that hammers out the relations between the city administration and BP. Batam agency. Regrettably, the government regulation has not been enacted. Consequently many people consider $\mathrm{Ba}$ tam to be administered and directed by two Captains. In reality, however, $\mathrm{Ba}$ tam is on island that is running on two engines, one engine is BP. Batam and the other is Batam city government. The hope is that equipped with two engines, Batam Island will run even faster than other regions in achieving its development goals. That is our hope."

Based on the excerpt of the interview with the BP.Btam official, there are some key issues that are important to note. Based on BP. Batam officials, Batam Island can achieve faster development because it is running on two engines. To achieve such a feat, the two engines must have the same institutional characteristics such as authority, organizational structure, autonomy space, and financing. Implicit in the remarks is that BP. Batam perceives the organizational structure of their organization to be similar to Batam city government. This is unlikely to be the case given the reality that BP. Batam was established to execute certain functions that were delegated to it by the central government while Batam city administration like other regional autonomy governments is tasked to conduct many functions. In short, BP. Batam considers its institutional framework to be similar to that of a regional autonomy polity.

With regards to the division of authority between BP. Batam and Batam city administration, is very clear that BP. Batam is vested with more powers (superior) than Batam city government. In light of that, 
officials of Batam city administration recommend the clear division of functions between the two institutions. The following is an excerpt of an interview to that effect:

"...If it is determined that BP. Batam has jurisdiction over 26 points that fall under the industrial zone, while Batam city government is charged with administering residential areas, then the former must limited its authority to administering the industrial area and the city administration, the nonindustrial part of the Island. Thus BP. Batam must administer only those 26 points, perhaps by starting with the 8 points upstream. This is the point that I raised while attending a meeting in the Ministry charged with economic coordination in Jakarta. My view is that as long as the issue of work relations is not delineated clearly, the infighting between the two institutions will never see an end. The working areas for each institution must be clear and well streamlined. That is the main reason why during the campaigns we proposed abolishing imposing tax on housing. Surprisingly, WTO was not reduced, but rather raised. Please be sympathetic to us.

...Imagine, residents are forced to pay WTO for residential housing while at the same time they are repaying installments on their home mortgages. Real estate developers pay WTO on land that is still under contestation and disputes. An example is land that categorized as forest conservation zone, but estate developers have already bought and paid for such land. The is more so given the subscription that has risen in multiples in the order of 148 PMK times."

Based on the except of an interview from Batam city administration officials in relation to making clear division and distribution of functions reflects the interest of the city government to urge the formation of a special economic zone that will be administered by BP. Batam in conducting all its activities.

\section{Structure of membership of the region- al council}

In order to reduce the potential for conflicts between the two institutions, the Batam free trade and harbor zone council was formed. The council is charged with the task of mapping the general policies, provide guidance, supervision, and coordination of activities of Batam free trade and harbor zone. As BP. Batam is an agency that was formed by the government to manage and administer certain functions in Batam region, the formation of the council was based on a presidential instruction. It seems that the governor who has limited authority that is attached to an ex officio as the head of the free trade and harbor zone council has its own problems. The problems which were disclosed by an informant who is a law practitioner in Batam in an interview with the author that went as follows:

\begin{abstract}
"A zone or area that is designated to become an investment destination must have many specialties such as fiscal, taxation, and others, will face obstacles in coordinating with the central government given the limited authority the governor, as an ex officio member of regional council has. This is especially so with regards to the authority that is not within the purview of the head of a regional autonomy administration. In other words, the governor will face the situation whereby as head of the council s(he) has no power to make some of the key decisions that relate to activities of the free trade and harbor zone on such issues as taxation, customs and excise, operational permits and others as such authority is vested in ministries and institutions."
\end{abstract}

Based on the above advice and inputs, it was deemed necessary to form a new Batam region council which underpinned by Presidential instruction No. 8 / 2016 on the Batam region council (DK Batam). The instruction above places the Minister of Coordination for Economic affairs as head of the council (DK Batam). Members of restructured DK Batam council are Ministry of coordination for economic affairs as the head as well as serving as 
member of the council, and Minister of internal affairs, Minister of legal and $\mathrm{Hu}-$ man rights affairs, Minister of Finance, Minister of Trade, Minister of Agrarian and Spatial planning, Indonesian armed forces commander, Indonesian police chief, Cabinet secretary, Governor of Riau islands province, Batam city major, and head of Riau islands provincial assembly. The new presidential instruction, thus, shifted the leadership of the regional council from the governor to the Minister of coordination for Economic affairs, which is expected to shorten the decision making process that require the involvement of sectoral ministries, governments institutions and non-ministerial institutions.

In relation to the composition of $\mathrm{Ba}$ tam regional council, BP. Batam officials expressed their string opposition to any efforts to include representatives of the business community on the council as a pathway to influence decisions it will make in future. This was evident in the expression of an official from BP. Batam that goes as follows:

"...No there is no indication that the policy direction is moving toward that way Mister. We indeed are an agency that is managed and administered as direct represented of the central government. Thus, we do not have direct relation to the local community because the agency is not an outcome of a directly elected elections by the local citizenry. As for involving members of the business community as members of the council, it must be noted that the council is a regulating agency, making it inappropriate for businessmen who are regulated to become members as well. We do not know for sure. Nonetheless, we can say for certain what the future holds. After all, there is nothing impossible in Indonesia.

...there are no indications that things are going toward that direction. Aspirations of the business community are channeled directly to BP. Batam through the head or deputy head. Once every 2 months BP. Batam invites investors, an FGD that involves association of Japanese and Singapore investors. This is in other words semiprofessional mechanism, where BP. Batam proac- tively invites investors. We have sub directorate that conducts evaluation. It is that institution that conducts visits to businesses to assess the progress of their activities. I reckon that companies do not want and expect their representatives of the regional council. Essentially whenever a complaint arises, we discuss it together. "

To that end, based on excerpt of the interview above, it is apparent that a new agency, the regional council, which represents central government authority at the local level is now in place. Nonetheless, the contents of the interview also disclosed another reality which is that the council include representatives of users of services it delivers, interalia, investors and businessmen. Criticism was also leveled at the council one of the informants who was interviewed for this study, who noted that its constituents make it unlikely to function as a legislative body that can make policies (performing legislative function) on issues that relate to free trade and harbor that emanate from the public.

Convening routine meetings on a continuous basis serves, which is coupled with proactively inviting service users, are the mechanisms the council uses to tackle complaints and conflicts that arise as well as deliberate on inputs from users of its services. Officials of BP. Batam consider such mechanisms are sufficient to tackle any problems that arise that relate to the functions that fall under their jurisdiction. To that end, mechanism the regional council uses are starkly different from the Administrative Committee model which Shanghai FTZ in China has adopted and employs. The Administrative Committee in Shanghai FTZ representatives of stakeholders who are within the jurisdiction of the Shanghai FTZ area, hence was not established by the central government, in which this case, the President of China (Tantri, 2013). Thus, Shanghai FTZ representative body represents users of services FTZ delivers in addition to representatives of relevant Ministries and Shanghai city government. 


\section{Institutional Ambiguity of Bp. Bantam in State Administrative Structure}

The management of free trade and free harbor zone in accordance to the existing regulation is under the control of a nonstructural institution which delivers general services. It is thus an irony that a non-structural organization is charged with executing functions that that constitute the authority of the President. In other words, if BP.Batam is viewed from the perspective of state administration in Indonesia, is constitutes the fourth authority with the same level of authority as commissions, only that BP. Batam conducts tasks that relate to construction of roads, hospitals, and other functions that fall under the jurisdiction of the executive arm of government.

"...which institution oversees the operation of BP. Batam? If it is under the central government, it becomes an agency that is conducts functions of the central government but is located in upcountry, which should also means there is autonomy. This is because there is no single ministry that oversees its work and functions. With respect to the structure, BP. Batam is not under the oversight of anybody. This is in contravention of article 17, of the 1945 Indonesian constitution that stipulates that the President in conducts his or her duties with the assistance of ministers. That is how the logic goes."

It has been noted that at the outset that the establishment of BP. Batam as a special institution by the government was aimed at conducting specific functions. This is in contravention of the current BP. Batam functions. Nonetheless, BP. Batam officials were not receptive to the suggestion that BP. Batam should focus on conducting FTZ functions, while Batam city government handles other functions. According to Batam city government, BP. Batam should be limited to those of its predecessor that is Batam authority. This was confirmed in an interview with an officials of Batam city government:

"...actually we were given special authority and powers. We would like to restore Batam to the status it used to have during the time when Batam achieved phenomenal development. That is what we aspire to achieve. What is surprising, however, is that the authority we have has been curtailed.

...the fact that widening the authority and power that is vested in BP. Batam is fine as long as such a process strengthens and streamlines its authority. Today, whenever investors come to Batam they demand and ask for stability, security, and investor friendly policies. The implication of that is there is no longer time for red tape. The reality says otherwise. This is because since the creation of Batam city government, Batam has been managed and administered by two institutions that thus vested with authority to issue operational permits. The best option is for BP. Batam to be charged with the function of issuing operational permits. In other words, in future only one institution should have the authority to issues operational permits. "

Based on viewpoints obtained from BP. Batam officials, it is apparent that they are not open to any possibility of narrowing the authority of BP. Batam to managing and administering FTZ related functions. Such a standpoint is contrary to opinions which the research team obtained from several experts concerning the issue of managing a special purpose area that is limited to conducting a specific purposel single purpose. The need for establishing such an agency is very much in line with Humes' statements (Humes, 1959) that "The Special-purpose authority is distinguished from the special purpose deconcentrated agencies of the central government bureaucratic hierarchy by the fact that it is outside this administrative hierarchy and has a representative governing organ, whose members may be selected in one or more following ways".

As regards funding the implementation of functions that fall under the jurisdiction of BP. Batam, officials who are employees of the institution noted that there are two types of funding sources, interalia government non tax revenues (PNBP) and pure Rupiah". The sources cited by BP. Batam officials are line with those that are recommended by the regulatory frame- 
work that underpins the formation of BP. Batam. Based on the regulation, funding sources for BP. Batam include a) compensation for services BP. Batam delivers to the community; b) outcome of collaboration with other parties; c) grants received in accordance with prevailing regulatory framework; d) Right to manage land; and / or e) outcome of other economic activities. Besides, BP. Batam is allowed to receive other incomes from the national budget (APBN) and local government budget (APBD). With regards to funding sources for BP. Batam, there is an interesting element which is the funding source from the local government, which in this case is Batam city government. The irony is BP. Batam, which has vast authority and power, is expected to receive funding from Batam city administration, which limited authority.

Apparently, funding from Batam city government is in the form of seconded funding or funding that the city government allocates to BP. Batam to conduct activities that relate to public services. Doubtless, the above arrangement is starkly different from what obtains in the managing of funding sources in Shanghai FTZ. The conduct of Shanghai FTZ activities makes financial contribution from the local government virtually impossible. This is indeed the inference that Guangwen (Guangwen, 2003) makes with respect to funding arrangements for Shanghai FTZ activities as reproduced in the following excerpt:

"...means that the financial incentives and special economic and administrative privileges are applied to a "zone", which are not enjoyed by domestic economics, and the national tax system, other foreign trade restrictions, and some economic and administrative policy would not be active within this zone; This freedom includes the free flow of commodities, capital, service and personnel between the zones and world economy as well as some administrative privileges. In other words, the zone enjoys economic incentives and privileges (preferential policy).",

It is thus evident that the management of free trade and free harbor (BP. Batam), despite showing potential signs to that end, has yet to have the special characteristics that indicate its fully fledged orientation toward functional decentralization. With regards to the relations with the central government, BP. Batam is still very dependent on the former. This is indeed a direct consequence of the nature of the organization which is special institution that the government established and conferred a lot of authority to execute the management of free trade and free harbor activities.

\section{Construction of Decentralization govern- ance in Irrigation, Education, and Free trade sectors in the Decentralization Poli- cy in Indonesia in future}

Administering and regulating collaboration and cooperation among local governments as stipulated in the new law on local governments is applicable to all government functions with the proviso or condition that joint management and administration of such functions generate externalities across local governments and enhance efficiency in public service delivery. Regulation on cooperation and collaboration as stipulated in Law on local governments divides voluntary and obligatory joint collaboration. Collaboration among local governments that share borders and those that don't, but considered to enhance effectiveness if consummated are categorized as voluntary. Meanwhile, collaboration that is based on the need to enhance externalities and efficiency in public service delivery is considered obligatory.

To that end, the existence of such regulatory framework, creates an opportunity for collaboration among local governments on one hand, and between the central government and local governments on the other in the management of government functions that are considered to have externalities for contiguous and non-contiguous regions underpinned by the goal of fostering economies of scale.

The central government can recentralize a function, and form a board whose members are drawn from the central government and local government stakeholders. This was reflected in results of a research by 
Muzawardi (Muzwardi, 2015). This was what the research referred to as CrossAgency's Partnership Characteristics in Investment Service Delivery which is involve collaboration among various stakeholders (Figure 1).

Figure 1 shows the potential for the formation of boards to support the management and administration of the delivery of services Batam free trade zone. Nonetheless, the model of collaboration is not representative of all stakeholders that use the services the board delivers such as national chamber of commerce and industry (KADIN), association of Indonesia businessmen (APINDO) and others. Relating the model of collaboration to the concept of Good Governance), a board can be likened to a service delivery contract between the government and service users which Kumorotomo refers to as the Citizen Charter in service delivery (Kumorotomo, 2007). Citizen Charter as a contract of delivering services to the public in order to enable them fulfill their political rights as citizens. The political contract specifically for the function of free trade and can be incorporated into activities of boards , which by extension can be implemented in the realm of irrigation and education administration within the framework of functional decentralization.

Reconstruction of good governance in sectoral decentralization which is the cornerstone of this research can be achieved due to the existence of mechanisms that are conducive for functional decentralization in the decentralization policy in Indonesia. Despite the fact the Indonesian constitution does not contain provisions on the use of other mechanism, the potential for reconstruction of good governance in decentralization policy which is based on the devolution of functions in accordance with territory can be complemented by other mechanisms. Such an opinion was confirmed in an interview with an expert who was a key informant of this research. "...in fact decentralization policy In Indonesia is very much based on territory or area, which is why mechanisms that are used in decentralization of functions are limited to decentralization, deconcentration, and the lower tier administration executing functions of the central government. Nonetheless, other mecha- nisms can be employed in the administration and management of functions through the issuing relevant laws despite the fact the constitution does not have provisions on that". In addition, "essentially, Indonesian 1945 constitution before amendment was flexible to the execution of regional and administrative government on the basis of territory both larger and small".

Ideally, reconstruction of good governance in Indonesian decentralization in future especially in education, irrigation, and free trade can be achieved piecemeal. First, collaboration and cooperation mechanism among local governments in the management of functions that have high externalities as well as collaboration between local governments and the central government, after which the central government establishes boards that comprise representatives of the central government, local governments, and stakeholders. Secondly, functions that are by nature Trans regional (involve more than one local government) such as River Cilicis and free trade can directly be management under the mechanism of functional decentralization. Meanwhile, education administration prior to implementing functional decentralization, requires equalization (reducing disparity in education quality across both local governments and schools, making good use of the standards that were set in 2013 curriculum.

The renewal, which is referred to above, relates to a process that should lead to zone based in a gradual manner in a phased manner that should not take unnecessary long time based on 2013 curriculum as quality insurance. Indeed, officials in the ministry of education acknowledge that the adoption of K-13 will first of all start with elementary and junior schools that have achieved a minimum of 6.5 in their national examination results and 80 percent of their teachers are certified. Subsequently the curriculum will be adopted at higher education levels. The policy is trying to reduce the wide disparity in schools by eliminating schools that have been associated with high competitiveness or favorites. If and when all schools have the same quality, the zone based system in enrolling new students can be implemented.

The condition in BP. Batam which is a 
multi-function of multipurpose institution viewed from the prism of a local government, must be forced to reduce its authority in line with initial functions that enshrined in its vision, missions, and goals at its inception. Such a step must be done because Batam city government duplicates more or less the same functions as BP. Batam. Meanwhile, on the issue of irrigation administration, P3A which is vested with the authority to administer and manage tertiary irrigation should have more authority that should include managing secondary and primary irrigation as well. This should apply to education administration when and if the quality of education among schools will be the same.

Maksum explains that the central established special local institutions in order to manage functions that are trans-regional in nature hence can be conducted by a single local government (Maksum, 2006). To that end, such an institution or agency must be supervised and overseen and accountable to the President. As the President faces constraints in conducting direct supervision and oversight over such institutions or agencies, institutions which have representatives of stakeholders were formed to do such function on behalf of the President. Direct users of services that are executed by special agencies (farmers and businessmen) have an opportunity to monitor directly the performance of their representatives as well as employees of such institutions on the ground. Based on the foregoing, this research proposes the following reconstructed model of functional decentralization as depicted in Figure 2.

To incorporate the above proposal, the central government can make use of the article on centralization in the Indonesian basic constitution, which is the President holds the ultimate responsibility to execute government functions. Besides, alternatively, the formation of functional decentralization can be made on the basis of serving national strategic interest. Such an argument was reflected in an interview the author had with an expert on administration which went as follows:

"Special region or zone is national interest and is therefore there to serve national interest, the interest of the unitary republic of Indonesia (NKRI) supersedes all others, those of local governments, inclusive. Nonetheless, the existence of a special institution that serves national interest in the area that is the jurisdiction of the local government must be on condition that the latter is well aware of the authority that is vested in the institution that serves national interests. When the authority of the special region or zone is located in the area that is under the jurisdiction of the local government, the President can retract or withdrawal the authority and hand it over to a special region or zone. "

Based on the excerpt of the interview above, it become clear that the juxtaposition of operational areas for special zones and local government, is bound to generate problems in the implementation of functional decentralization in special zones or regions. To that end, there is need to form representative agencies or bodies that comprise stakeholder of special zone or region. Figure 3 depicts the mechanisms that are proposed to implement the formation of functional decentralization:

The central government retracted or recentralize the authority to administer and manage irrigation, education, and free trade functions with the purpose of achieving economies of scale, national strategic interests and high externalities. Besides, the Indonesian constitution mandates that the President is the ultimate authority over administrative issues in the context of the united republic of Indonesia. After that the central government can restore or devolve the authority to manage the functions to local stakeholders, who subsequently manage such using democratic means through the formation of representative institutions that comprise representatives of the central government, local governments and users in the area where the institution is located or operates. Representatives can be directly elected by users, selected or appointed by the government.

\section{CONCLUSION}

Reconstruction of good governance in irrigation, education, and free trade functions in the decentralization policy in Indonesia 


\section{Cross-Agency's Partnership Characteristics in Investment Service Delivery}

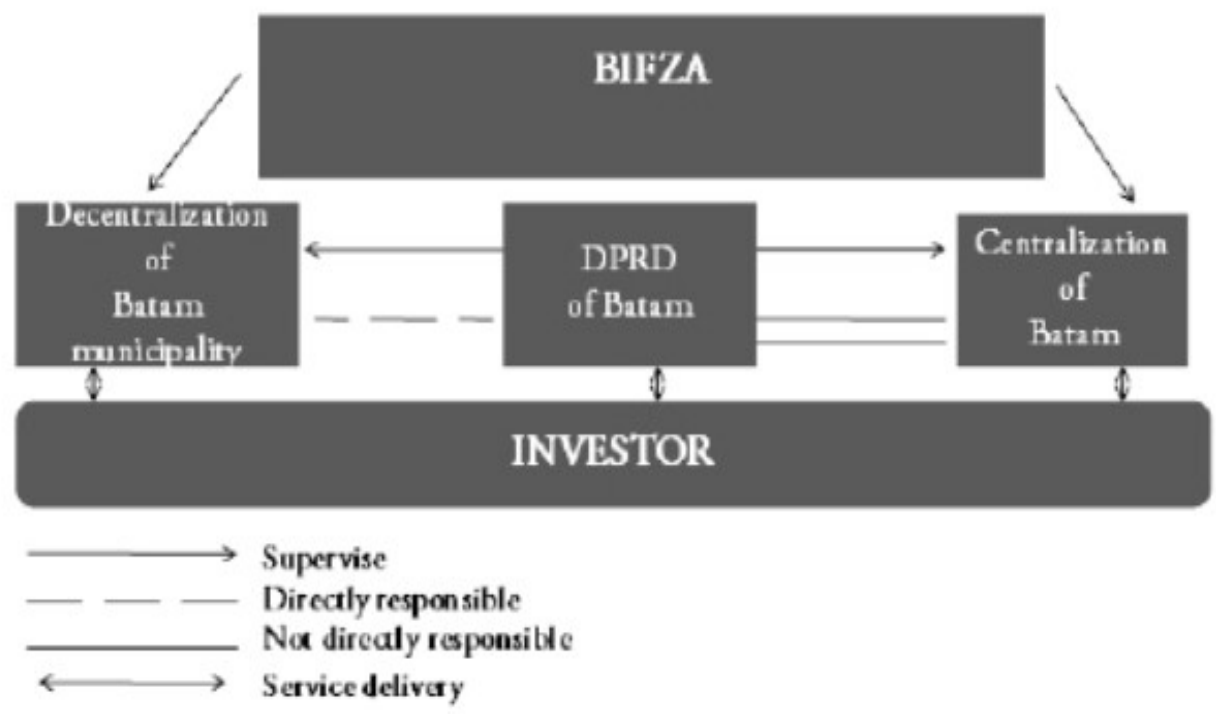

Figure 1. Partnership Characteristics in Investment Service Delivery

Source : (Muzwardi, 2015)

can be executed in a phased manner by paying serious attention to collaboration among local governments using cooperation mechanisms among local governments, and fostering collaboration between the central government and local governments in administering certain functions which form the foundation of boards. Subsequently, the central government forms functional decentralization based institution through the retraction or withdrawal of the authority to administer and manage irrigation, education and free trade functions initially, and afterwards devolve such authority democratically elected local stakeholders. Several factors are responsible for absence of functional decentralization policy in the administration of irrigation, education and free trade functions. The main factor, however, is absence in the provisions of Indonesian constitutions that stipulates on functional decentralization in the three functions. To that end, it is not unfathomable that article 18, Indonesian 1945 constitution should be amended to provide the highest normative foundation for functional decentralization. Nonetheless, considering the formidable difficulty of amending the constitution, another alternative should be to amend the existing law on local government. The amendment should allow democratically elected local stakeholders to have the authority to manage certain functions.

\section{REFERENCES}

Cuadrado-Ballesteros, B. (2014). The impact of functional decentralization and externalization on local government transparency. Government Information Quarterly, 31(2), 265-277. https:// doi.org/10.1016/j.giq.2013.10.012

Cuadrado-Ballesteros, B., García-Sánchez, I. -M., Prado-Lorenzo, J.-M., \& GarcíaSanchez, I.-M. (2016). Determinants of functional decentralization and their relation to debt: empirical evidence based on the analysis of Spanish municipalities. International Review of $\mathrm{Ad}$ ministrative Sciences, 79(4), 701-723. https:// doi.org/10.1177/0020852313501246

Guangwen, M. (2003). The Theory and Practice of Free Economic Zones: A Case Study of Tianjin, People's Repub- 


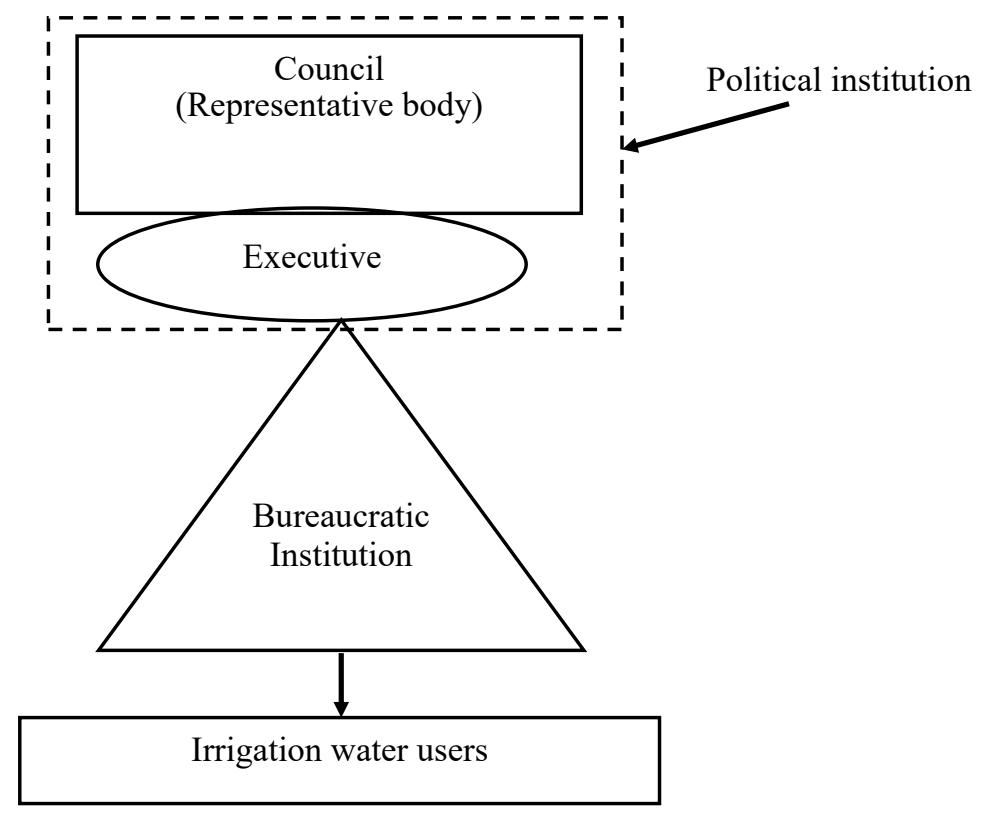

Figure 2. Structure of Special Local Government

Source : Maksum, 2006

lic of China. Tianjin.

Hamidah, U. (2015). Pengaturan Hukum Pengelolaan Sumber Daya Air di Kota Bandar Lampung. Cita Hukum, 2(2), 322.

Hoessein, B. (1993). Berbagai Faktor yang Mempengaruhi Besarnya Otonomi Daerah Tingkat II. Universitas Indonesia.

Humes, S. (1959). The Structure of Local Governments throughout the World: A Comparative Introduction. USA: Springer.

Hung, N. K. (2009). Political and Administrative Decentralization in Vietnam. In S. Ichimura \& R. Bahl (Eds.), Decentralization Policies in Asian Development (Vol. 1, p. 228). London: World Scientific. https://doi.org/10.1017/ CBO9781107415324.004

Kuks, S. (2002). The Evolution of the $\mathrm{Na}$ tional Water Regime in the Netherlands. Twente: Center for Clean Technology and Environmental Policy (CCTE).

Kumorotomo, W. (2007). Citizen Charter (Kontrak Pelayanan): Pola Kemitraan Strategis untuk Mewujudkan Good Governance dalam Pelayanan Publik. Jakarta.

Kuswandi, A. (2011). Desentralisasi Pen- didikan dalam Penyelenggaraan Otonomi Daerah di Indonesia. Governance, 2 (1), 69-98.

Lan, G. Z. and G. C. (2010). Intergovernmental Relations in Mainland China. In E. M. Berman (Ed.), A Companion to Ancient Greek Government (pp. 7596). New York: CRC Press. https:// doi.org/10.1002/9781118303214.ch19

Li, B. (2012). Engineering, Development and Philosophy, 11, 23-37. https:// doi.org/10.1007/978-94-007-5282-5

Maksum, I. R. (2006). Desentralisasi dalam Pengelolaan Air Irigasi Tersier (Suatu Studi dengan Kerangka Konsep Desentralisasi Teritorial dan Fungsional di Kabupaten dan Kota Tegal-Jawa Tengah, di Kabupaten Jembrana-Bali, serta di Hulu Langat-Selangor Malaysia). Makara, Sosial Humaniora, 10(1), 1-7.

Maksum, I. R. (2007). Memahami Desentralisasi Fungsional (Perbandingan Praktek di Belanda, Jepang, USA dan Jerman). Indonesian Journal of International Law, 4(3), 498.

Maksum, I. R. (2016, June). Darurat Desentralisasi Fungsional. Kompas, p. 7.

Murti, M. S. (2014). Urgensi Otonomi Khusus Batam dikaitkan dengan Pelaksanan Masyarakat Ekonomi Asean 2015. Jurnal Rechts Vinding, 3(2), 215-235. 
Alma'arif and Irfan Ridwan Maksum — Functional Decentralization Construct in Decentralization Policy....
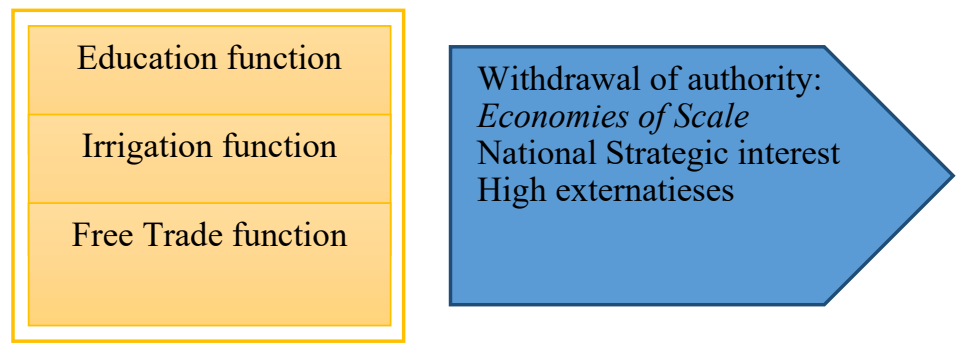

\section{Central government}
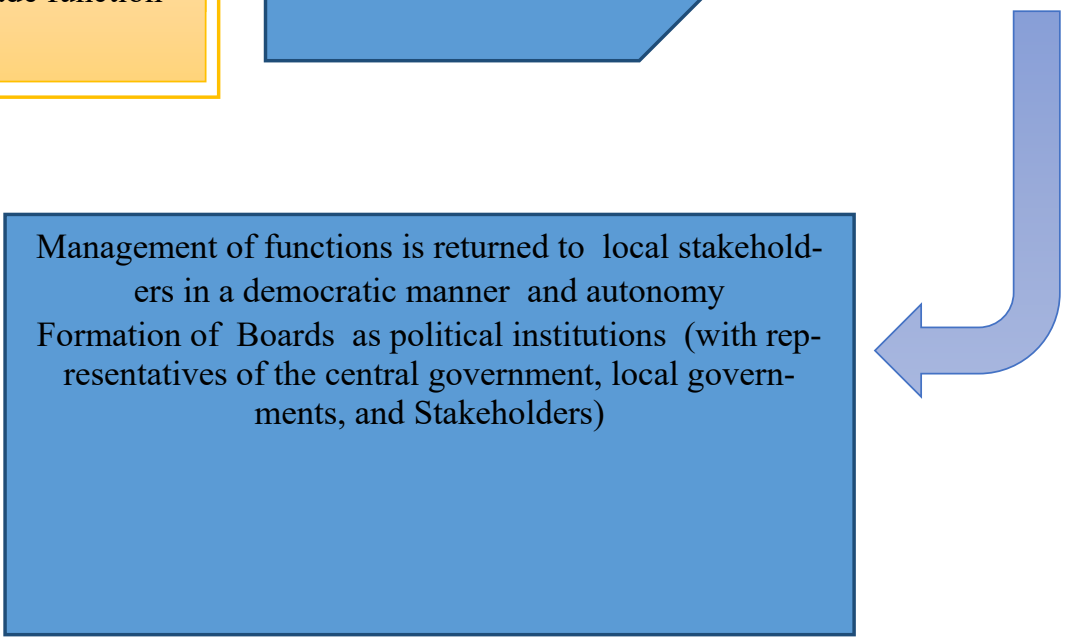

Figure 3. Mechanisms for the Formation of Functional Decentralization

(Data analysis)

Muzwardi, A. (2015). The Analysis of Network Governance in the Investment Development of Free Trade Zone and Free Port ( KPBPB ) Batam. Jurnal Kebijakan Dan Administrasi Publik (JKAP), 19(2), 145-155.

Pasandaran, S. (2004). Desentralisasi Pendidikan dan Masalah Pemberdayaan Sekolah, 11(2), 115-129.

Selin, H. (2011). Governing the Tap: Special District Governance and the New Local Politics of Water. By Megan Mullin. Cambridge, \{MA: $\}$ MIT $\}$ Press, 2009. 280p. $\$ 44.00$ cloth, $\$ 22.00$ paper. Perspectives on Politics, 9(1), 105107. https:// doi.org/10.1177/1078087409360649

Sidik, F. (2015). Menggali Potensi Lokal Mewujudkan Kemandirian Desa. Jurnal Kebijakan Dan Administrasi Publik (JKAP), 19(2), 115-131.

Tantri, M. L. (2013). Trajectories of China's Integration with the World Economy through SEZs: A Study of Shenzhen SEZ. China Report (Vol. 49). https:// doi.org/10.1177/0009445513491526

Xu, S. (n.d.). China's Public Administration Reform: New Approaches. Retrieved from http://www.iam.or.jp/asiapacific panel/pdfdownloads/athens01paper4.pdf. 